\title{
The Effects of Teaching Lexical Collocations on Speaking Ability of Iranian EFL Learners
}

\author{
Elahe Movahediyan Attar \\ Najafabad Branch, Islamic Azad University, Najafbad, Iran \\ Hamid Allami \\ Yazd University, Yazd, Iran
}

\begin{abstract}
The present study aimed at a) investigating the effect of teaching collocations on the speaking ability of EFL Iranian Learners, b) examining the relationship between the participants' knowledge of collocations and the participants' use of collocation taking into consideration, and c) finding out participants' attitude towards teaching collocations. To this end, after administrating the Quick Placement Test (QPT), 40 intermediate $\mathrm{L} 2$ learners were selected out of 80 , and assigned to two experimental and control groups. For pretests, collocation test and collocation interview were run. Then, Collocation in Use was taught to the experimental group as a treatment. After collocation instruction, another collocation test and interview were conducted on both experimental and control group. The result of paired sample $t$-test showed that the participants' speaking ability in the experimental group significantly improved in posttest. The analyzed data also revealed that after the collocation instruction in experimental group the participants' performance in interview increased too. Moreover, the result of ANCOVA displayed that the participants had positive attitudes towards explicit instruction of collocations. This study has theoretical and pedagogical implications in the field of foreign/second language teaching and learning. It can be considered as a solution for language teachers, constantly searching for the better ways to train native-like speakers.
\end{abstract}

Index Terms - speaking ability, knowledge of collocation, use of collocation, collocation

\section{INTRODUCTION}

One of the most difficult tasks of foreign/ second language learners is appropriately combining words in L2. In contrast to L2 speakers, native speakers have the knowledge about which words go together and how to use the diverse words. Having such knowledge is one of the vital competencies of native speakers. These combinations of words are referred to as "collocations". The proper use of collocations is crucial to sound like a native speaker (Ellis, 1996), yet this is not so easy for non-native speakers of a target language (Vasiljevic, 2008).

Using collocations accurately is necessary in order to produce language with native-like accuracy or near-native competency. However, even advanced ESL/EFL learners have trouble with collocations. Learners in EFL settings typically have problem of lacking exposure to the target language and consequently, they are often not aware of the differences in collocational restrictions between the L1 and the L2. The gap between L1 and L2 interferes with learners' acquisition of collocations in the target language and might "even lead to lexical fossilization" (Vasiljevic, 2008, p. 3). The other difficulty in learning collocations is that learners' knowledge of collocations does not expand in parallel with their knowledge of general vocabulary. Because of their relative transparency in meaning, collocations offer L2 learners little difficulty in terms of comprehension. However, collocations are more problematic when they are used in productive skills, such as speaking and writing, than in receptive skills, such as listening and reading. Even if learners can manage to guess the meanings of collocations in receptive processes, they might not be able to use them properly in reproducing the language. Thus, producing collocations requires pedagogical treatment.

Nattinger (1988) states that the meaning of a word mostly depends on the other words that it collocates with; by the help of these collocates the learner keeps the words in memory and can easily infer the meaning from the context. He also argues that the notion of collocations is extremely important for acquiring vocabulary but its potential has not been fully utilized.

Similarly, Chan and Liou (2005) explain that teaching of collocations in English foreign language classes have not got enough attention; as a result, students learning English as a foreign language are weak in collocation use. Rather than teaching vocabulary as single lexical items which causes a lexical incompetence on the part of learners, students must be made aware of the necessity of acquiring collocations.

\section{BACKGROUND}

Collocations are recognized as a crucial part of language use and distinguish native speakers and non-native speakers (Ellis, 2001; Fontenelle, 1994; Herbst, 1996; Koya, 2006; Lennon, 1996; Moon, 1992; Nation, 2001; Wouden, 1997). Many researchers conducted empirical studies found EFL teachers and practitioners figured out English collocations too 
diverse, yielding findings of limited practical value. For instance, numerous pioneer studies only examined EFL/ESL learners' knowledge of collocations (Bahns \& Eldaw, 1993; Biskup, 1992; Farghal \& Obiedat, 1995; Keshavarz \& Salimi, 2007; Zughoul \& Abdul-Fattah, 2003) or explored how EFL/ESL learners made errors1 of collocation (Huang, 2001; Jeng, 2006; Liu, 1999a, 1999b; Lombard, 1997; Wu, 2005). Only recently have we seen studies targeting the possible connection between collocations and general language skills (Al-Zahrani, 1998; Bonk, 2000; Sung, 2003).

One of the researches was investigated the knowledge of English lexical collocations among four academic levels of Saudi EFL university students and the relationship between the participants' collocational knowledge and their general language proficiency. Al-Zahrani found that among the different academic years there was a substantial difference in his subjects' knowledge of lexical collocations. The knowledge of lexical collocations improved with the subjects' academic years. Above and beyond, he reported that there was a strong correlation between the subjects' knowledge of collocations and their language proficiency.

Lin (2002) surveyed the impact of collocation instructions on receptive and productive collocation competence of high-achievers and low-achievers in a group of EFL high school students. The results indicated that all students made more progress in receptive collocation tests than productive ones, but low-achievers performed better in productive tests after collocation teaching. Both groups held positive attitudes toward collocation teaching activities.

Tseng (2002) divided 94 high school participants into an experimental group, who received 12 weeks of explicit collocation instruction, and a control group, who did not receive any training. After collocation instruction, the experimental group far exceeded the control group in the post-test regardless of their prior collocation levels.

Sung (2003) looked at the knowledge and use of English lexical collocations in relation to speaking proficiency of international students enrolled in a university in Pittsburgh area. A total of 72 non-native English speakers and 24 native English speakers participated in her study. Her results showed that there was a significant correlation between the knowledge of lexical collocations and the subjects' speaking proficiency.

Koosh and Jafarpour (2006) investigated the role of the Data-Driven Learning (DDL) and the concordance materials in the production of collocation of prepositions. Their findings recommended a new approach, such as DDL, towards the teaching of collocations using concordance material. They also come to this conclusion that learners" difficulty in spoken and written product is not related to their grammatical or lexical knowledge but to lack of knowledge of the words accompanies it, that is, the collocation.

Rahimi and Momeni (2012) examined the effects of teaching vocabulary through collocation and concordance techniques on language proficiency. The results showed that teaching vocabulary has an effect on the improvement of language proficiency and vocabulary teaching, be traditional methods such as translation, explanation and definition or new trend of collocation teaching of the words, can bring about a significant growth in language proficiency.

A conclusion reached by a number of studies is that learners use overall fewer collocations than native speakers (e.g. Hasselgren 1994; Howarth 1996; Kaszubski 2000; Granger 1998; Lorenz 1999) except for the small number of frequent ones which are overused (Kasuzbki, 2000). Other recurrent findings have been that learners are not aware of restrictions (e.g. Herbust, 1996; Howarth, 1996), but that they are at the same time not aware of the full combinatory potential of words they know (Channell, 1981; Granger 1998). Individual studies have indicated that learners are insecure in the production of collocations (Burgschmidt \& Perkins, 1985) and that the collocation problems are more serious than general vocabulary problems (Bahns \& Eldaw, 1993).

Research Questions

This study will shed light on the following questions:

1) Does teaching collocation have any significant effect on speaking ability of Iranian EFL learners?

2) Is there any relationship between participants' knowledge and use of collocations in speaking?

3) What are the learners' attitudes towards teaching collocations?

Research Hypotheses

The first two research questions learnt themselves to be reformulated in the form of following null hypotheses:

Ho1: Teaching collocation has no effect on speaking ability of Iranian EFL learners.

Ho2: There is no relationship between the participants' knowledge of collocation and the participants' use of collocations in vocabulary.

\section{MethodOLOGY}

\section{Participants}

The participants who were studying at intermediate level were selected. They took Quick Oxford Placement Test (QOP) and 40 out of 80 were chosen to participate in this study. They were 31 females and 9 males with the age range of 17 to 32. All of them spoke Persian as the same mother language and they had never lived abroad. They had been studying English for 2 years at Shokouhe Tarbiat Institute in Isfahan. They had been learning English through American Headway Book 3 at intermediate level.

Instrument

In this study, the participants were given QPT test, a collocations test, a collocation interview and they answered a questionnaire before and after the treatment. 
For selecting the intermediate students, QPT, version1, was used. This test is divided into two parts: Part 1 (Questions 1-40) and Part 2 (Questions 41-60). The participants whose proficiency scores of the test were between one standard deviation above and below the mean were selected to take part in this study.

Collocation test which was used as the pretest and posttest involved 30 multiple choice items. It was administrated to all forty students with the scores from 0 to 30. All of collocations were selected according to 10 units of 'English Collocations in Use' which is written by Michael McCarthy and Felicity O'Dell. Reliability of collocation test was calculated and it was 0.82 .

Then the participants took part in a ten-minute interview, as a pretest and posttest, with the aim of considering the effects of teaching collocations on speaking ability. The 10-minute interview consisted of twenty questions in two parts: comprehension and production. In the comprehension part interviewer asked 10 questions which included collocations and students had to comprehend them to answer.

Next, the students answered other ten questions to produce the collocations. They had to talk about some topics, describe some pictures and complete some sentences to use the collocations. Each question had one score and the total score was out of twenty. The inter-rater reliability was calculated (.899) which is significant at the $\mathrm{p}=0.01$.

A questionnaire was given to the participants before and after the treatment to collect information about participants' attitude in learning collocation. This questionnaire shed light on the better ways of learning collocations for intermediate students.

\section{PROCEDURE}

First, QPT was given to 80 students. This placement test consisted of 60 items with 30 vocabulary items and 30 grammar items. This test was given to four classes that involved 20 students in it. They were permitted to answer it in only in 30 minutes. The aim of this test was to homogenize and select intermediate level students. Forty out of eighty students were selected. Then, they were divided into two groups: 20 students in the control group and 20 students in the experimental group.

All of forty students were fallen through pre-tests including a collocation test, an interview and a questionnaire. Only 20 minutes was allocated for answering the 30-item collocation test. The participants had to choose one of the four choices to fill in the gaps with the correct collocations. After that, each one took part in an interview with 20 questions. It took each participant 10 minutes to answer them. Students circled the best choice on the questionnaire according to their attitudes of learning English collocations.

After the pretest session, students in the experimental group were engaged in a treatment which was ten sessions on learning lexical collocations. Each session was one hour and three times in a week. In the first session, they were taught one unit of the book 'English Collocation in Use'. They were asked to practice the collocation exercises by making example sentences in which those collocations were used. Then, they had to do the exercises in the following pages. In the second session, the instructor went through the new units, after she made some questions of the previous unit. This procedure was the same for following sessions. The selection of these units, as it was mentioned in this book, was based on more useful collocations in written and spoken English and the collocations which were less obvious and the Cambridge Corpus shows can be problematic.

One week after the treatment, as the posttest, another collocation completion test which was parallel to the first one was administrated along with 10-minute interview was conducted. Again the collocation questionnaire was given to the participants in order to determine the possible changes in their attitudes of learning vocabulary through lexical collocations.

During these four weeks of experiment, while the experimental group used the lexical collocations, the control group didn't receive lexical collocations instruction. The other procedures like time limits, the content of completion test and interview (in pre and post test) were the same for control group.

\section{RESUlt}

\section{Descriptive Statistics for Oxford Proficiency Test}

As it was previously mentioned, 31 female and 9 male students participated in this study were studying English as a foreign language at Shokouhe Tarbiyat Institute in Isfahan. In order to make sure that the participants had enough knowledge of vocabulary, an Oxford Placement Test developed by Allen (2004) was administrated in 30 minutes. Table 1.1 shows the number of students, mean and standard deviation.

TABLE 1.1

RESULTS OF DESCRIPTIVE STATISTICS OF OPT

GroupStatistics

\begin{tabular}{|c|c|c|c|c|c|}
\hline & group & $\mathrm{N}$ & Mean & Std. Deviation & Std. Error Mean \\
\hline \multirow[t]{2}{*}{$\overline{\mathrm{OPT}}$} & experimental & 20 & 31.50 & 2.373 & .531 \\
\hline & control & 20 & 31.35 & 1.814 & .406 \\
\hline
\end{tabular}


40 students whose scores were 1 SD above and 1 SD below the mean were selected from the main sample. The table displays that experimental group and the control group were found to be at similar levels of English proficiency because their means are fairly similar (control group=31.50, experimental group=31.35). To find out whether these two means are statistically different or not, an independent samples $t$-test was run in Table 1.2.

TABLE 1.2

RESULTS OF INDEPENDENT SAMPLE T-TEST OF OPT

Independent Samples Test

\begin{tabular}{|c|c|c|c|c|c|c|c|c|c|c|}
\hline & & \multicolumn{2}{|c|}{$\begin{array}{c}\text { Levene's Test for Equality } \\
\text { of Variances }\end{array}$} & \multicolumn{7}{|c|}{ t-test for Equality of Means } \\
\hline & & \multirow[b]{2}{*}{$\mathrm{F}$} & \multirow[b]{2}{*}{ Sig. } & \multirow[b]{2}{*}{$\mathrm{t}$} & \multirow[b]{2}{*}{ df } & \multirow[b]{2}{*}{ Sig. (2-tailed) } & \multirow[b]{2}{*}{ Mean Difference } & \multirow{2}{*}{$\begin{array}{l}\text { Std. Error } \\
\text { Difference }\end{array}$} & \multicolumn{2}{|c|}{$\begin{array}{l}95 \% \text { Confidence Interval of } \\
\text { the Difference }\end{array}$} \\
\hline & & & & & & & & & Lower & Upper \\
\hline \multirow[t]{2}{*}{ OPT } & Equal variances assumed & .043 & .836 & .225 & 38 & .824 & .150 & .668 & -1.202 & 1.502 \\
\hline & Equal variances not assumed & & & .225 & 35.556 & .824 & .150 & .668 & -1.205 & 1.505 \\
\hline
\end{tabular}

The above table shows that the experimental group and the control group were equal in terms of English proficiency before the treatment, $\mathrm{t}(38)=.22$, $\mathrm{p}>.05$. In other words, the mean score of control group was not distinctly different from the mean score of experimental group in English proficiency before the treatment.

Results of Pre-tests

Before the treatment a collocation test was given to participants to measure their knowledge of collocation. In addition, they were asked to sit for a collocation interview to measure their ability in using of collocations in their speaking. Table 1.3 displays the mean and standard deviation.

TABLE 1.3

RESUlTS OF COLLOCATION PRETEST AND INTERVIEW PRETEST

\section{GroupStatistics}

\begin{tabular}{lllrrr}
\hline \hline & group & $\mathrm{N}$ & Mean & Std. Deviation & Std. Error Mean \\
\hline collocation pretest & experimental & 20 & 6.65 & 1.599 & .357 \\
& control & 20 & 6.20 & 2.167 & .484 \\
\hline \multirow{2}{*}{ interview pretest } & experimental & 20 & 6.70 & .979 & .219 \\
& control & 20 & 6.25 & 1.446 & .323 \\
\hline \hline
\end{tabular}

As the table shows the mean scores of collocation test for experimental group and control group are 6.65 and 6.20, which indicates that they had nearly similar knowledge of collocations. The mean score of participants on interview pretest for the experimental group was 6.70 and for the control group was 6.25 showing that both groups were fairly similar in terms of collocation knowledge and collocation use.

Two independent Sample $t$-test were run to find out any significant differences in pretests. Table 1.4 shows the results.

TABLE 1.4

INDEPENDENT SAMPLE T-TEST OF PRETESTS

Independent Samples Test

\begin{tabular}{|c|c|c|c|c|c|c|c|c|c|c|}
\hline & & \multicolumn{2}{|c|}{$\begin{array}{c}\text { Levene's Test for Equality } \\
\text { of Variances }\end{array}$} & \multicolumn{7}{|c|}{$\mathrm{t}$-test for Equality of Means } \\
\hline & & \multirow[b]{2}{*}{$\mathrm{F}$} & \multirow[b]{2}{*}{ Sig. } & \multirow[b]{2}{*}{ t } & \multirow[b]{2}{*}{$\mathrm{df}$} & \multirow[b]{2}{*}{ Sig. (2-tailed) } & \multirow[b]{2}{*}{ Mean Difference } & \multirow{2}{*}{$\begin{array}{l}\text { Std. Error } \\
\text { Difference }\end{array}$} & \multicolumn{2}{|c|}{$\begin{array}{l}95 \% \text { Confidence Interval of } \\
\text { the Difference }\end{array}$} \\
\hline & & & & & & & & & Lower & Upper \\
\hline \multirow[t]{2}{*}{ collocation pretest } & Equal variances assumed & 1.781 & .190 & .747 & 38 & .459 & .450 & .602 & -.769 & 1.669 \\
\hline & Equal variances not assumed & & & .747 & 34.956 & .460 & .450 & .602 & -.772 & 1.672 \\
\hline \multirow[t]{2}{*}{ interview pretest } & Equal variances assumed & 8.171 & .007 & 1.152 & 38 & .256 & .450 & .391 & -.341 & 1.241 \\
\hline & Equal variances not assumed & & & 1.152 & 33.383 & .257 & .450 & .391 & -.344 & 1.244 \\
\hline
\end{tabular}

As the table represents, the amount of $t$ for collocation pretest is $t(38)=.7747, p>.05$. It indicates that the result is not significantly different between the mean scores of two groups. For interview pretest, it shows $t(38)=1.125, p>.05$. It means that the differences between the participants' mean scores in both control and experimental group in the pretest are not significant. In other words, there were no significant differences between the performances of participants in control and experimental groups in pretests and before the treatment. In fact, both groups were homogeneous regarding knowledge of collocations before the treatment. 
Results of the Effects of Teaching Collocations on the Speaking Ability of EFL learners

The first research question aimed to examine significant effects of teaching collocations on speaking ability of Iranian EFL learners. In order to answer this question, the descriptive statistics participants' performances on the pretests and posttests of the control group (CG) and the experimental group (EG) were calculated. Table 4.5 tabulates the descriptive statistics of the control group and experimental group.

TABLE 1.5

RESUlTS OF DESCRIPTIVE STATISTICS OF THE CG AND EG IN PRETEST AND POSTTEST

PairedSamples Statistics

\begin{tabular}{|c|c|c|c|c|c|c|}
\hline group & & & Mean & $\mathrm{N}$ & Std. Deviation & Std. Error Mean \\
\hline \multirow[t]{4}{*}{ experimental } & Pair 1 & collocation pretest & 6.65 & 20 & 1.599 & .357 \\
\hline & & collocation posttest & 18.95 & 20 & 4.032 & .902 \\
\hline & Pair 2 & interview pretest & 6.70 & 20 & .979 & .219 \\
\hline & & interview posttest & 14.90 & 20 & 2.713 & .607 \\
\hline \multirow[t]{4}{*}{ control } & Pair 1 & collocation pretest & 6.20 & 20 & 2.167 & .484 \\
\hline & & collocation posttest & 6.45 & 20 & 1.669 & .373 \\
\hline & Pair 2 & int erview pretest & 6.25 & 20 & 1.446 & .323 \\
\hline & & interview posttest & 5.05 & 20 & 1.276 & .285 \\
\hline
\end{tabular}

As the table shows the mean score of the experimental group has increased from collocation pretest (6.65) to collocation posttest (18.95). The same rise is easily noticeable in interview pretest (6.70) to posttest interview (14.90). For control group, the mean scores of collocation tests also increase, but this rise is trivial from pretest (6.20) to posttest (6.45). The performance of control group on interview from pretest (6.25) to posttest (5.05) decreases.

Table 1.6 shows the homogeneity of the participants in both control and experimental groups by running an independent sample $t$-test.

TABLE 1.6

RESULT OF INDEPENDENT SAMPLE T-TEST OF THE CG AND EG

PairedSamples Test

\begin{tabular}{|c|c|c|c|c|c|c|c|c|c|c|}
\hline \multirow[b]{3}{*}{ group } & & & \multicolumn{5}{|c|}{ Paired Differences } & \multirow[b]{3}{*}{$\mathrm{t}$} & \multirow[b]{3}{*}{$\mathrm{df}$} & \multirow[b]{3}{*}{ Sig. (2-tailed } \\
\hline & & & \multirow[b]{2}{*}{ Mean } & \multirow[b]{2}{*}{ Std. Deviation } & \multirow[b]{2}{*}{ Std. Error Mean } & \multicolumn{2}{|c|}{$\begin{array}{l}95 \% \text { Confidence Interval of } \\
\text { the Difference }\end{array}$} & & & \\
\hline & & & & & & Lower & Upper & & & \\
\hline \multirow[t]{2}{*}{ experimental } & Pair 1 & $\begin{array}{l}\text { collocation pretest - } \\
\text { collocation posttest }\end{array}$ & -12.300 & 3.962 & .886 & -14.154 & -10.446 & -13.885 & 19 & .000 \\
\hline & Pair 2 & $\begin{array}{l}\text { interview pretest - } \\
\text { interview posttest }\end{array}$ & -8.200 & 2.215 & .495 & -9.237 & -7.163 & -16.558 & 19 & .000 \\
\hline \multirow[t]{2}{*}{ control } & Pair 1 & $\begin{array}{l}\text { collocation pretest - } \\
\text { collocation posttest }\end{array}$ & -.250 & 1.118 & .250 & -.773 & .273 & -1.000 & 19 & .330 \\
\hline & Pair 2 & $\begin{array}{l}\text { interview pretest - } \\
\text { interview posttest }\end{array}$ & 1.200 & 1.642 & .367 & .432 & 1.968 & 3.269 & 19 & .004 \\
\hline
\end{tabular}

As the table represents, the difference between participants' collocation performance from pretest to the posttest in the control group is not significant, $\mathrm{t}(19)=1.000, \mathrm{p}=.330>.05$. In other word, there is no significant improvement in the control group from pretest to posttest. The paired sample test for control group indicates that participants' interview performance from pretest to posttest is negatively affected, $\mathrm{t}(19)=3.269, \mathrm{p}=.004<.05$. In other word, participants answered fewer oral questions in posttest than pretest. It seems that they avoided producing the collocations.

In contrast to control group, the experimental group performed significantly better from pretest to posttest on the collocation test, $t(19)=13.88, p=.000<.05$. It is as different as participants' interview performance in experimental group, $\mathrm{t}(19)=16.558, \mathrm{p}=.000<.05$. In other word, the performance of the participants in the experimental group significantly improved from pretest to posttest in both collocation and interview tests. Therefore, based on the obtained and analyzed data, it can be concluded that teaching collocations had a positive and significant effect on the participants' speaking ability.

Result of the Relationship between Participants' Knowledge of collocation and Participants' Use of Collocation

The purpose of the second research question was to determine whether there was any relationship between participants' knowledge of collocations and participants' use of collocations. The Pearson Correlation was used to 
measure correlations between the scores of knowledge of lexical collocations and use of collocations among all subjects. The results displays in Table 1.7.

TABLE 1.7

RESULTS OF PEARSON CORRELATION BETWEEN COLLOCATION TEST AND COLLOCATION INTERVIEW IN PRE AND POSTTEST

\begin{tabular}{|c|c|c|c|c|c|}
\hline \multicolumn{6}{|c|}{ Correlations } \\
\hline & & $\begin{array}{c}\text { collocation } \\
\text { pretest }\end{array}$ & $\begin{array}{l}\text { interview } \\
\text { pretest }\end{array}$ & $\begin{array}{c}\text { collocation } \\
\text { posttest }\end{array}$ & $\begin{array}{c}\text { interview } \\
\text { posttest }\end{array}$ \\
\hline \multirow[t]{3}{*}{ collocation pretest } & Pears on Correlation & 1 & -.045 & .280 & .139 \\
\hline & Sig. (2-tailed) & & .785 & .080 & .393 \\
\hline & $\mathrm{N}$ & 40 & 40 & 40 & 40 \\
\hline \multirow[t]{3}{*}{ interview pretest } & Pears on Correlation & -.045 & 1 & $.326^{*}$ & $.331 *$ \\
\hline & Sig. (2-tailed) & .785 & & .040 & .037 \\
\hline & $\mathrm{N}$ & 40 & 40 & 40 & 40 \\
\hline \multirow[t]{3}{*}{ collocation posttest } & Pears on Correlation & .280 & $.326 *$ & 1 & $.934^{*}:$ \\
\hline & Sig. (2-tailed) & .080 & .040 & & .000 \\
\hline & $\mathrm{N}$ & 40 & 40 & 40 & 40 \\
\hline \multirow[t]{3}{*}{ interview posttest } & Pears on Correlation & .139 & $.331 *$ & $.934 *>$ & 1 \\
\hline & Sig. (2-tailed) & .393 & .037 & .000 & \\
\hline & $\mathrm{N}$ & 40 & 40 & 40 & 40 \\
\hline
\end{tabular}

*. Correlation is significant at the 0.05 level (2-tailed).

**. Correlation is significant at the 0.01 level (2-tailed).

As the table displays, Pearson correlation between collocation test and collocation interview in pretests was $r=0.04<$ $\mathrm{p}=0.05$. In other words, the relationship was not significant between participants' knowledge and use of collocations or it is better to say that there was no relationship between collocation knowledge and collocation use among participants.

After the treatment, results revealed that the relationship between knowledge of lexical collocations' scores and use of lexical collocations' scores was positively correlated. Statistically significant correlation existed between the collocation knowledge's scores and collocation use's scores for the participants $(r=.94>p=0.05)$. In brief, there was a positive correlation between participants' knowledge and use of collocations

Result of Learning Collocation Questionnaire

The last question of this study concerned participants' perceptions and opinions about the learning collocations and its impact on speaking. To analyze the questions individually before and after the treatment, first the descriptive statistics were calculated. Tables 1.8 show the results.

TABLE 1.8

RESULTS OF DESCRIPTIVE STATISTICS FOR LEARNING COLLOCATION QUESTIONNAIRE

\begin{tabular}{|c|c|c|c|c|c|c|}
\hline & & & Mean & $\mathrm{N}$ & Std. Deviation & $\begin{array}{c}\text { Std. Error } \\
\text { Mean }\end{array}$ \\
\hline \multirow{26}{*}{ experimental } & Pair & $q 1$ & 3.50 & 20 & .946 & .212 \\
\hline & 1 & q1 & 2.60 & 20 & .883 & .197 \\
\hline & Pair & 92 & 2.70 & 20 & 1.455 & .325 \\
\hline & 2 & $q^{2}$ & 1.95 & 20 & 1.146 & .256 \\
\hline & Pair & 93 & 3.15 & 20 & .813 & .182 \\
\hline & & q3 & 2.65 & 20 & 1.137 & .254 \\
\hline & Pair & q3 & 3.25 & 20 & .910 & .204 \\
\hline & & 93 & 3.55 & 20 & .945 & .211 \\
\hline & Pair & q3 & 2.35 & 20 & .933 & .209 \\
\hline & & 93 & 2.75 & 20 & .967 & .216 \\
\hline & Pair & q4 & 2.90 & 20 & .718 & .161 \\
\hline & & 94 & 3.60 & 20 & .503 & .112 \\
\hline & Pair & 95 & 1.75 & 20 & 1.209 & .270 \\
\hline & & q5 & 2.20 & 20 & 1.005 & .225 \\
\hline & Pair & q6 & 3.55 & 20 & .826 & .185 \\
\hline & & 96 & 3.70 & 20 & 1.081 & .242 \\
\hline & Pair & 97 & 3.10 & 20 & 1.119 & .250 \\
\hline & & $q 7$ & 3.55 & 20 & .999 & .223 \\
\hline & Pair & 98 & 2.65 & 20 & 1.496 & .335 \\
\hline & 10 & 98 & 3.00 & 20 & 1.451 & .324 \\
\hline & Pair & q9 & 3.45 & 20 & 1.276 & .285 \\
\hline & 11 & q9 & 3.40 & 20 & 1.188 & .266 \\
\hline & Pair & q10 & 4.05 & 20 & 1.050 & .235 \\
\hline & 12 & q10 & 4.80 & 20 & .410 & .092 \\
\hline & Pair & q11 & 3.65 & 20 & 1.040 & .233 \\
\hline & 13 & q11 & 3.85 & 20 & .875 & .196 \\
\hline
\end{tabular}

For determining its level of significant sample t-tests were run. Table 1.9 represents the results. 
TABLE 1.9

RESUlT OF PAIRED-SAMPLE T-TEST FOR LEARNING COLLOCATION QUESTIONNAIRE

Paired Samples Test

\begin{tabular}{|c|c|c|c|c|c|c|c|c|c|c|}
\hline & & & \multicolumn{5}{|c|}{ Paired Differences } & \multirow[b]{3}{*}{$\mathrm{t}$} & \multirow[b]{3}{*}{ df } & \multirow[b]{3}{*}{ Sig. (2-tailed) } \\
\hline & & & \multirow[b]{2}{*}{ Mean } & \multirow[b]{2}{*}{ Std. Deviation } & \multirow{2}{*}{$\begin{array}{l}\text { Std. Error } \\
\text { Mean }\end{array}$} & \multicolumn{2}{|c|}{$\begin{array}{l}95 \% \text { Confidence } \\
\text { Interval of the } \\
\text { Difference }\end{array}$} & & & \\
\hline \multicolumn{3}{|l|}{ group } & & & & Lower & Upper & & & \\
\hline \multirow[t]{13}{*}{ experimental } & Pair 1 & $q 1-q 1$ & .900 & 1.210 & .270 & .334 & 1.466 & 3.327 & 19 & .004 \\
\hline & Pair 2 & $q^{2}-q_{2}$ & .750 & 1.251 & .280 & .164 & 1.336 & 2.680 & 19 & .015 \\
\hline & Pair 3 & $q^{3}-q^{3}$ & .500 & 1.670 & .373 & -.282 & 1.282 & 1.339 & 19 & .196 \\
\hline & Pair 4 & $q^{3}-q^{3}$ & -.300 & 1.218 & .272 & -.870 & .270 & -1.101 & 19 & .285 \\
\hline & Pair 5 & $q^{3}-q^{3}$ & -.400 & 1.353 & .303 & -1.033 & .233 & -1.322 & 19 & .202 \\
\hline & Pair 6 & $q 4-q 4$ & -.700 & .733 & .164 & -1.043 & -.357 & -4.273 & 19 & .000 \\
\hline & Pair 7 & q5 - q5 & -.450 & 1.099 & .246 & -.964 & .064 & -1.831 & 19 & .083 \\
\hline & Pair 8 & $q 6-q 6$ & -.150 & 1.137 & .254 & -.682 & .382 & -.590 & 19 & .562 \\
\hline & Pair 9 & $q^{7}-q^{7}$ & -.450 & 1.317 & .294 & -1.066 & .166 & -1.528 & 19 & .143 \\
\hline & Pair 10 & $q 8-q 8$ & -.350 & 1.663 & .372 & -1.128 & .428 & -.941 & 19 & .358 \\
\hline & Pair 11 & $q 9-q 9$ & .050 & 1.638 & .366 & -.716 & .816 & .137 & 19 & .893 \\
\hline & Pair 12 & $q 10-q 10$ & -.750 & .967 & .216 & -1.202 & -.298 & -3.470 & 19 & .003 \\
\hline & Pair 13 & $q_{11}-q_{11}$ & -.200 & 1.196 & .268 & -.760 & .360 & -.748 & 19 & .464 \\
\hline
\end{tabular}

The mean scores of experimental group for questions $1,2,4$ and 10 are respectively $.900, .750, .700$ and .750 . They are significant at $\mathrm{t}(19)=.004$, $\mathrm{t}$ $(19)=.015, \mathrm{t}(19)=.000$ and $\mathrm{t}(19)=.003$.

Within the learning collocation questionnaire items, the purpose of items, 1 and 2 were to determine the participants' attitudes towards teaching collocations on their speaking ability. For these two items the number of scales was revised; totally disagreement $=5$, partially disagreement $=4$, no comment $=3$, partially Agree $=2$ and totally Agree $=1$. The following table shows the results of this investigation.

TABLE 1.10

RESULTS OF ITEMS 1 AND 2

\begin{tabular}{|c|c|c|c|c|c|}
\hline & & Frequency & Percent & Valid percent & $\begin{array}{l}\text { Cumulative } \\
\text { percent }\end{array}$ \\
\hline \multirow[t]{5}{*}{ Item One } & Valid 5 & 1 & 5.0 & 5.0 & 5 \\
\hline & 4 & 10 & 50.0 & 50.0 & 55.0 \\
\hline & 3 & 5 & 25.0 & 25.0 & 80.0 \\
\hline & 2 & 4 & 20.0 & 20.0 & 100.0 \\
\hline & Total & 20 & 100 & 100 & \\
\hline \multirow[t]{6}{*}{ Item Two } & Valid 5 & 9 & 45.0 & 45.0 & 45.0 \\
\hline & 4 & 6 & 30.0 & 30.0 & 75.0 \\
\hline & 3 & 3 & 15.0 & 15.0 & 90.0 \\
\hline & 2 & 1 & 5.0 & 5.0 & 95.0 \\
\hline & 1 & 1 & 5.0 & 5.0 & 100.0 \\
\hline & Total & 20 & 20 & 20 & \\
\hline
\end{tabular}

Table 1.11 displays the frequency and percentage of the participants' choices regarding the effects of collocation instruction on their speaking ability. The scale of partially disagree $=4$ and totally disagree $=5$ have the highest frequency. It shows their positive attitudes towards learning collocation and the relationship between collocation knowledge and their speaking ability. In other words, students believe that collocation instruction makes them to focus on the words accompanying and recall them while they are speaking.

Items 4 and 10 intended to determine the participants' attitudes to how important collocation learning is in classroom setting. Table 1.12 represents the results.

TABLE 1.12

RESULTS OF ITEMS 4 AND 10

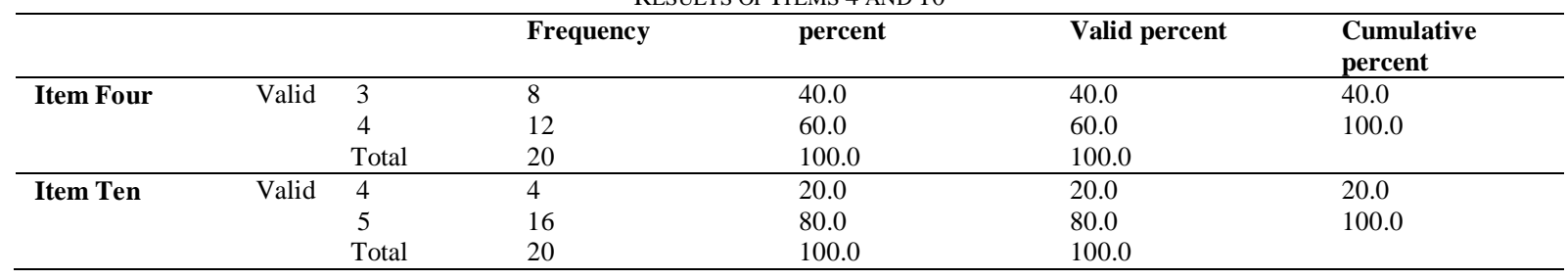

Table 1.12 indicates the frequency of choices the participants selected regarding teaching collocations. The scales of very important $=4$ and totally agree $=5$ have the highest frequency. In other words, participants agreed that collocation instruction is very important in English learning. As the participants mentioned learning collocations in classroom setting is the best way for learning collocations. The frequency of choices the participants selected regarding these items indicates their positive attitudes towards learning collocations in classroom setting.

\section{DISCUSSION}

In the present study, an attempt was made to investigate the impact of teaching collocations on speaking ability of intermediate EFL Iranian learners. This experimental research supports the claim that the teaching of collocation has a direct influence on the learners' speaking ability. There is almost lack of literature to be compared with this study. In 
this domain, Tim Hus (2008) and his colleagues in their study sought to find appropriate answer to this question. They wanted to know whether the knowledge and use of English lexical collocations is related to speaking proficiency of Taiwanese EFL students enrolled in a university in Taiwan. Like the present study, they used instruments such as a collocation test and speaking tests to collect appropriate data. The first test was used to measure the participants' knowledge of collocations by the participants' scores on the fill-in the-blank lexical collocations while the latter was used to elicit the participants' use of lexical collocations and their speaking proficiency by the participants' scores in Pear Film test and Phone Pass spoken English test. In contrary to present study, this study did not employ any collocation instruction treatment and the researcher participated EFL junior university students.

Therefore, the result of the present study is partly in contrast and partly in accordance with the result of that study. In Tim Hus et al.'s study, the comparison of data indicated that the more collocation knowledge the speaker had, the more proficient the speaker was. The result of Tim Hus's study is the same as the present study which there is a significant correlation between the knowledge of lexical collocation and the subjects' speaking proficiency. On the other hand, in Tim Hus et al.'s study there was no significant relationship between the use of collocation and speaking proficiency of learners, although in the present study the use of collocation proved the learners' speaking ability.

Regarding the second research question, the analysis of the data reveals that collocation knowledge improved use of collocations in intermediate Iranian EFL learners. The result conform some other scholars (e.g. Gitsaki, 1996; Lombard, 1997; Tseng, 2002). This result also obtained in Al-Zahrani's (1998) study. In that study, the researcher investigated the relationship between English lexical collocation knowledge and their general language proficiency among four academic levels of university students. The data, received by a cloze test and TOFEL test, showed the strong correlation between the participants' knowledge of collocations and their use of collocations, which is in line the result of the current study.

In another study, Tseng (2002) compared an experimental group, received 12 weeks of explicit collocation instruction, and a control group who was not under the treatment procedure. The results of that study like the present study showed that the experimental group outperformed the control group on participants' collocation use.

While Zhang (1993) took consideration of writing skill in their studying, they also reached the conclusion that collocation knowledge is in relation to use collocation among intermediate students. It is while the participants of Zhang's study (1993) were also the same as the present study but participants were divided in two groups of native and non-native speakers of English. Zhang's study showed English native speakers used more collocations in their writings than non-native speakers. The present study also improved its positive effects on the intermediate level group.

Moreover, the result of the present study is partly in accordance and partly in contrast with the results of study conducted on different L1. Howarth's study (1996) demonstrated verb-noun combinations in a corpus of 10 essays were fewer in nonnative speakers than native speakers. However, the result of Howarth's (1996) study was a little bit different that there was no relationship between the knowledge of collocations and the collocation used. Contrary, the present study showed that the knowledge of collocations affected on participants' collocation use.

Concerning the last research question, i.e., the participants' attitudes concerning collocation instruction, the finding of the present study was again in accordance with some other studies (Abdaoui, 2010; Çakır \& Balc1, 2011).

There are several possible explanations for the beneficial effects of explicit collocation instruction in this study. The result of this study gives evidence to support that teaching collocations that enhances speaking ability in EFL contexts results in empowering students in three ways: first, they can use language that they already partly know. Second, the rate of processing and producing of language is much faster by learning collocations and, third, increasing their awareness that they can identify the powerful partnerships in a text (Daniela Forquera, 2006).

According to Warning (1997), instead of learning individual words, our mind tend to use chunks in a way that when we are going to speak or write, it is more efficient to remember chunks or phrases rather than constructing single words at once. Additionally, he states that native speakers will consciously predict what they are going to say. Therefore, if a non-native speaker uses unusual phrases, it becomes hard to comprehend. An increase in students' knowledge of collocations results in the improvement of their oral and reading comprehension. It means, since grammar, vocabulary and meaning work together to make a learner competent in language, it will be a mistake to neglect any of them or not to pay enough attention to them (Schmitt \& McCarthy, 1990)

\section{CONCLUSION}

To summarize, the major goal of the present study was to determine the extent to which lexical collocation teaching, especially the use of collocation knowledge, can develop L2 learners speaking proficiency. It is done while making L2 learners native-like and fluent speaker which is one of the teachers' aim.

The findings of this study reveal that teaching lexical collocation is a useful mean to maximize collocation knowledge, having positive effects on Iranian EFL learners' speaking ability. It appears that through the use of collocation knowledge, L2 learners can manage to have more control over speaking ability in English and comprehend the ideas within the dialogues and conversations. In addition, L2 learners' responses to collocation questionnaire confirmed that they have positive attitudes towards learning collocation in classroom settings and its impact upon speaking ability. 


\section{REFERENCES}

[1] Al-Zahrani, M. S. (1998). Knowledge of English lexical collocations among male Saudi college students majoring in English at a Saudi university. Unpublished doctoral dissertation, Indiana University of Pennsylvania, Pennsylvania.

[2] Balc1, Özgül \& Çakır, Abdülkadir. (2012). Teaching vocabulary through collocations in EFL Classes: The case of Turkey. International Journal of Research Studies in Language Learning, Volume 1, Number 1, 21-32.

[3] Bahns, J. (1993). Lexical Collocation: A contrastive view. ELT Journal, Oxford University Press, Vol. 47.

[4] Benson, M. (1990). Collocations and general-purpose dictionaries. International Journal of Lexicography, 2(1.2), 1-14.

[5] Biskup, D. (1990). "Some remarks on combinability: Lexical collocation." In: Janusz Arabski (Ed.), Foreign Language Acquisition Papers. (pp. 31-44) Katowice: Uniwersytet Slaski.

[6] Biskup, D. (1992). L1 influence on learners renderings of English collocations. A Polish/German empirical study. In: Anaund, P.J.L.,Bejoint, H. (Eds.), Vocabulary and Applied Linguistics. Macmillan, Basingstoke, 85-93.

[7] Brown, D.F. (1974). Advanced Vocabulary Teaching: the problem of collocation. RELC journal, 5(2), 1-11.

[8] Burns, A. (1998). Teaching Speaking. Annual Review of Applied Linguistics, 18, 102-123.

[9] Carter, R. (1998). Vocabulary: Applied Linguistic Perspective. London: Routledge.

[10] Ellis, N. C. \& Schmidt, R. (1997). Morphology and longer distance dependencies: Laboratory research illuminating in SLA. Studies in Second Language Acquisition, Vo.19, pp. 145-171.

[11] Ellis, N. (1996). Sequencing in SLA: Phonological memory, chunking, and points of order. Studies in Second Language Acquisition, Vo. 18, pp. 91-126.

[12] Fan, M. (2004). An exploratory study of collocational use by ESL students- A task based approach, Issue 1, March 2009, (pp. 110-123)

[13] Farrokh, Parisa. (2012). Raising Awareness of Collocation in ESL/EFL Classrooms. Journal of Studies in Education. Vol. 2, No. 3 .

[14] Firth, (1957). Papers in Linguistics 1934-1951 (pp. 190-215). London OUP.

[15] Ganji, Mansour. (2012). On the Effect of Gender and Years of Instruction on Iranian EFL Learners' Collocational Competence. Canadian Center of Science and Education, Vol. 5, No. 2. Received, October 2012, from www.ccsenet.org/elt.

[16] Gitsaki, C. (1999). Second Language Lexical Acquisition: The development of ESL collocation knowledge, Bethesda, MD: International Scholars Publications.

[17] Green, F. \& Christopher, E. \& Lam, J. Developing discussion skills in the ESL classroom. In: Richards, Jack C. \& Renandy, W. (Eds.). Methodology in Language Teaching. Cambridge University Press, 225-234.

[18] Ha Le, Thanh. (2010). Learning Lexical Collocations with Concordancing and Scaffolding. University of Groningen, University of Groningen Press, 70-71.

[19] Hendricks, A. E., \& Yang, Y. (2002). Lexical collocations and transferability. Paper presented at the 2002 International Conference: English in South East Asia. Hong Kong Baptist University.

[20] Hill, J. (2000). Revising priorities: From grammatical failure to collocational success. In: Michael Lewis (Ed.), Teaching collocation (pp. 47-67). Hove, England: Language Teaching Publications.

[21] Hsu, J. Y. (2002). Development of collocational proficiency in a workshop on English for general business purposes for Taiwanese college students, Unpublished doctoral dissertation, Indiana University of Pennsylvania, Pennsylvania.

[22] Hsu, J.Y. (2007) Lexical Collocations and their Relation to the Online Writing of Taiwanese College English Majors and NonEnglish Majors, Electronic Journal of Foreign Language Teaching, Vol. 4, No. 2, 192-209.

[23] Hsu, L. C. (2005). The effect of lexical collocation instruction on Taiwanese college EFL learners' listening comprehension, Unpublished master thesis, National Kaohsiung First University of Science and Technology, Taiwan.

[24] Jafarpour A. \& Koosha M. (2006). Data-Driven Learning and Teaching Collocation of Prepositions. Journal of Faculty of Letters and Humanities, Year 49, No. 200.

[25] Jeon, J. (2009). The selection of collocations in media for KFL learners, KLing, 3, 39-50. Retrieved, October 2012 from www.kling.or.kr/pds/ kling200902/39-50.pdf.

[26] Juknevičienė, R. (2008). Collocations with High-Frequency Verbs in Learner English: Lithuanian Learners vs. Native Speakers. Vilnius University, Kalbotyra.

[27] Kennedy, G. (2003). Amplifier Collocations in the British National Corpus: Implications for English Language Teaching. TESOL Quarterly, Vol. 37, No. 3 (autumn, 2003), p. 467-487.

[28] Lewis, M. (2000). Teaching collocation: Further developments in the lexical approach. London: Language Teaching Publications.

[29] Lin, Y. P. (2002). The effects of collocation instruction on English vocabulary development of junior high school students in Taiwan. National Kaohsiung Normal University, Kaohsiung, Taiwan.

[30] Liu, C. P. (1999a). A study of Chinese culture university freshmen's collocational competence: "Knowledge" as an example. Hwa Kang Journal of English Language \& Literature, pp. 5, 81-99.

[31] McCarthy, M. (1990). Vocabulary. Oxford: Oxford University Press.

[32] McCarthy, M. \& O’Dell, F. (2007). English Collocations in Use. Cambridge University Press, pp. 6-39.

[33] Mounya A. (2010). Teaching Lexical Collocations to Raise Proficiency in Foreign Language Writing. Guelma University, Algeria.

[34] Mclntosh, C. \& Francis, B. \& Poole, R. (2009). Oxford Collocations Dictionary for students of English (2 ${ }^{\text {nd }}$ Ed.). Oxford University Press.

[35] Nesselhauf, N. (2003). The Use of Collocations by Advanced Learners of English and Some Implications for Teaching. Applied Linguistics, Oxford University Press, pp. 223-242.

[36] Palmer, H.E. (1993). Second Interim Report on English Collocation. Kaitakusha.

[37] Pokorná, T. (2009). Acquiring the English Collocations with some Element of Unpredictability: by means of chunking, comparing, guessing. Kristianstad University Press. Received, September, 2012, from www.google.com. 
[38] Rahimi M. \& Momeni G. (2012). The effect of teaching collocations on English Language Proficienc. Procedia- Social and Behavior Science, pp. 37-42.

[39] Renandya, W. \& Richards, J.C. (2002). Methodology in Language Teaching: An Anthology of Current Practice. Cambridge University Press, pp. 201-233.

[40] Richards, J.C. (1990). Conversational speaking: approaches to the teaching of conversation. In: Richards, J.C., The Language Teaching Matrix, New York: Cambridge University Press, pp. 67-85.

[41] Richards, J.C. (2008). Teaching listening and speaking: from theory to practice. New York, Cambridge University Press, pp. 19-28.

[42] Sadeghi K. (2009). Collocational Differences between L1 and L2: Implications for EFL Learners and Teachers. TESL Canada Journal, Vo. 26, No. 2. pp. 3-5.

[43] Shigeru, O. (2011). Teaching collocations effectively with the aid of L1. The Language Teacher (TLT) Takushoku University. p. 4.

[44] Shokouhi, H. \& Mirsalari, G.A. (2010). Collocational Knowledge versus General Linguistic Knowledge among Iranian EFL Learners. TESL-EJ 13.4. Received, October 2012, from www.google.com.

[45] Stockdale, J. G. (2004). Definition plus Collocation in Vocabulary Teaching and Learning. The Internet TESL Journal, Vol. X, No. 5. Received, October 2012 from: http://iteslj.org/Articles/Stockdale-Vocabulary.html.

[46] Tim Hsu J.Y. \& Chiu C.Y. (2008). Lexical Collocations and their Relation to Speaking Proficiency. The Asian EFL Journal, Volume 10, Number 1.pp. 3-11.

[47] Tsang, W.K. \& Wong, M. (2002). Conversational English: an interactive, collaborative and reflective approach. In: Richards, J.C. \& Rendandya, W. (Eds.) Methodology in Language Teaching, New York: Cambridge University Press, 212-224.

[48] Tseng, F. P. (2002). A study of the effects of collocation instruction on the collocational competence of junior high school students in Taiwan. Unpublished master thesis, National Taiwan Normal University, Taiwan.

[49] Vasiljevic, Z. (2008). Teaching vocabulary to advanced Japanese students: A word association approach. The East Asian Learner, 1-19.

[50] Webb, S. \& Kagimoto, E. (2009). The Effect of Vocabulary Learning on Collocation and Meaning. TESOL Quarterly 43, 5577.

[51] Wu, L. H. (2005). A study of English verb-noun collocational knowledge of technological university English majors in Taiwan. Unpublished master thesis, National Kaohsiung First University of Science and Technology, Taiwan.

[52] Zhang, X. (1993). English collocations and their effect on the writing of native and non-native college freshmen. Unpublished doctoral dissertation, Indiana University of Pennsylvania, Pennsylvania.

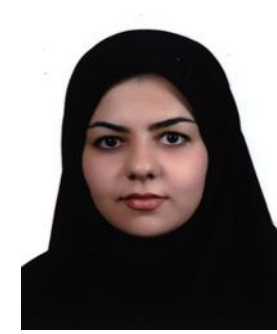

Elahe Movahediyan Attar holds an M.A in TEFL from Islamic Azad University, Najafabad Branch, Najafabad, Iran. She has extensive experience of teaching English as a foreign language. Her research interest includes testing, assessment and L2 acquisition.

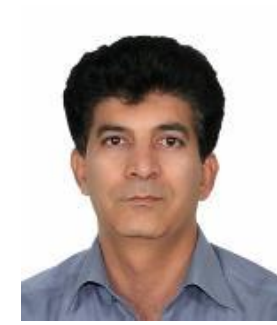

Hamid Allami is Assistant Professor of Applied Linguistics at Yazd University, Yazd, Iran. He has published articles on various topics in Applied Linguistics in several international journals. He has also presented papers in international conferences. His research interest includes sociolinguistics, discourse analysis, critical discourse analysis and genre analysis. 